\title{
The Clinicopathological and Prognostic Significance of IDO1 Expression in Human Solid Tumors: Evidence from a Systematic Review and Meta-Analysis
}

\author{
Cheng-Peng Yua, Shu-Fang Fu ${ }^{\mathrm{c}}$ Xuan-Chen ${ }^{\mathrm{b}} \quad$ Jing-Ye $^{\mathrm{b}} \quad$ Yuan-Ye $^{\mathrm{d}}$ \\ Ling-Dong Kong ${ }^{d} \quad$ Zheng-Ming Zhu ${ }^{a}$
}

\begin{abstract}
aDepartment of General Surgery, The Second Affiliated Hospital of Nanchang University, Nanchang, 'The Second Clinic Medical College of Nanchang University, Nanchang, 'Department of Nephrology, The Second Affiliated Hospital of Nanchang University, Nanchang, dThe Queen Mary College of Nanchang University, Nanchang, P. R. China
\end{abstract}

\section{Key Words}

Ido1 • Carcinoma • Prognosis • Meta-analysis

\begin{abstract}
Background/Aims: Indoleamine 2,3-dioxygenase 1 (IDO1) is a heme-containing enzyme catalyzing the initial and rate-limiting steps in the kynurenine pathway, which converts tryptophan into kynurenine. Upregulation of IDO1 decreases tryptophan levels and increases the accumulation of kynurenine and its metabolites. These metabolites can affect the proliferation of T cells. Increasing evidence has shown that IDO1 is highly expressed in various cancer types and associated with poor prognosis of cancer patients. However, the results were inconsistent. Methods: We searched the Web of Science, PubMed, Embase and Cochrane library databases to identify studies evaluating the prognostic value of IDO1 in cancer patients. Pooled hazard ratios (HRs) or odds ratios (ORs) with $95 \%$ confidence intervals (CIs) were calculated by using fixed-effects/random-effects models. Results: This systematic review and meta-analysis included 2706 patients from 24 articles. The results indicated a shorter overall survival in patients with high expression of IDO1 (hazard ratio $[\mathrm{HR}]=2.03,95 \%$ confidence interval [CI]: 1.56-2.63). Furthermore, disease-free survival was worse in patients with high expression of IDO1 (HR $=2.47,95 \% \mathrm{CI}: 1.46-4.20)$. Additionally, the pooled odds ratios (ORs) showed that increased IDO1 was significantly associated with tumor differentiation $(\mathrm{OR}=1.81$, 95\% CI: 1.05-3.12), distant metastasis (OR $=1.45$, 95\% CI: 1.02-2.06), and poor clinical stage $(\mathrm{OR}=1.89,95 \% \mathrm{CI}: 1.13-3.17)$. However, no significant correlation was observed of increased IDO1 expression with age, sex, lymph node metastasis, and tumor size. Conclusion: High expression of IDO1 is associated with poor clinical outcomes. IDO1 could serve as a biomarker

C.-P. Yu and S.-F. Fu contributed equally to this work.

Zheng-Ming Zhu

Department of General Surgery, The Second Affiliated Hospital of Nanchang University

Nanchang, Jiangxi 330000 (P. R. China)

E-Mail zzm8654@163.com
\end{abstract}

KARGER 


\section{Cellular Physiology Cell Physiol Biochem 2018;49:134-143 \begin{tabular}{l|l|l} 
DOI: 10.1159/000492849 & $\begin{array}{l}\text { O 2018 The Author(s). Published by S. Karger AG, Basel } \\
\text { www.karger.com/cpb }\end{array}$
\end{tabular}}

Yu et al.: The Expression of IDO1 in Human Tumors

of prognosis and a potential predictive factor of clinicopathology in various cancers. Further studies should be performed to verify the clinical utility of IDO1 in human solid tumors.

\section{Introduction}

Indoleamine 2, 3-dioxygenase 1 (ID01) is a heme-containing enzyme catalyzing the initial and rate-limiting steps in the kynurenine pathway, which catalyzes tryptophan into kynurenine. Overactivation of the kynurenine pathway results in a tryptophan decrease and kynurenine accumulation [1-3] . The former can result in the cell cycle arrest of immune cells, such as CD8+ T lymphocytes, natural killer (NK) cells, and invariant NK-T cells, via the general control non-depressible 2 stress kinase pathway and the mammalian target of rapamycin pathway [4-6]. The latter can cause the death of effector T cells due to the toxicity of its downstream product. Moreover, kynurenine can bind to aryl hydrocarbon receptor, which is involved in the regulation of Treg and inhibits TH17 cell differentiation, suppressing the immune system [7-10].

In 2003, Uyttenhove et al. found that ID01 was expressed in various human cancer tissues and that tumors expressing ID01 could resist immune rejection [2] . The following year, it was reported that ID01 was also expressed by dendritic cells in tumor-draining lymph nodes and that melanoma patients with IDO-positive cells in lymph nodes had a poor clinical outcome [11] . A relationship has been found between clinical outcome and the expression of ID01 in many human solid tumors, such as breast cancer, cervical cancer, colorectal cancer, endometrial cancer, and adrenal cell carcinoma [12-16]. However, the role of ID01 in malignant tumors is controversial. Patients with multiple tumor types, such as nasopharyngeal carcinoma, colorectal cancer, endometrial cancer, and ovarian carcinoma, have poorer prognosis if they have high ID01 levels [17-20]. In contrast, patients with high ID01 expression in some tumors, such as renal cell carcinoma (RCC), have a longer survival [12]. This systematic review and meta-analysis investigated the role of ID01 in human solid tumors.

\section{Materials and Methods}

\section{Literature search}

To identify potentially eligible studies, a comprehensive literature retrieval was conducted in PubMed, Web of Science, Embase, and Cochrane library databases with a cutoff date of December 15th, 2017. The keywords for the search were "indoleamine 2, 3-dioxygenase 1", "ID01", “cancer", "carcinoma”, "neoplasm", and "tumor". In addition, other relevant articles were also manually reviewed from the reference lists.

\section{Inclusion and exclusion criteria}

Inclusion criteria for the articles were as follows: (1) investigation of the role of ID01 in the development of human cancer; (2) description of the associations of ID01 expression with prognosis or clinicopathological features; (3) determination of the expression level of ID01 in primary cancerous tissue by immunohistochemistry, immunofluorescence, or quantitative real-time polymerase chain reaction (qPCR); (4) division of patients into high and low expression groups according to the expression level of ID01; and (5) no patients with HIV or active Epstein-Barr virus infection. Exclusion criteria were as follows: (1) duplicate publications; (2) studies without valuable data; and (3) reviews, letters, case reports, and expert opinions.

\section{Date extraction and quality assessment}

The data and information from all included studies were independently extracted by two investigators (FSF and CX). The following information was collected from each study: first author's name, publication year, study country, cancer type, total number of patients, tumor stage, follow-up period, outcome measures, criteria for high ID01 expression, determination method, hazard ratios (HRs), and corresponding 95\% 


\section{Cellular Physiology Cell Physiol Biochem 2018;49:134-143 \begin{tabular}{ll|l} 
and Biochemistry Published online: 22 August, 2018 & $\begin{array}{l}\text { (c) } 2018 \text { The Author(s). Published by S. Karger AG, Basel } \\
\text { www.karger.com/cpb }\end{array}$ \\
\hline
\end{tabular} \\ Yu et al.: The Expression of IDO1 in Human Tumors}

confidence intervals (CIs). In addition, data on clinicopathological parameters were also extracted from the eligible studies. For all included studies, only multivariate analysis was selected because of its increased precision in interpreting confounding factors. Any studies reporting only Kaplan-Meier curves and not providing multivariate data were excluded. In the event of a disagreement, a consensus was reached by a third investigator (YJ). The Newcastle-Ottawa Scale (NOS) was applied to assess the quality of all included studies. The NOS scores ranged from 0 to 9 , with an NOS score $\geq 6$ considered to indicate high quality. The quality of all studies included in this meta-analysis varied from 4 to 9 , with a mean value of 6.5.

\section{Statistical methods}

The current meta-analysis was performed with RevMan5.3 software and Stata SE12.0. Heterogeneity between studies was determined with the chi-square-based Q test and $I^{2}$ statistic. A P value less than 0.05 for the $\mathrm{Q}$ test and an $I^{2}$ value greater than $50 \%$ were considered to indicate significant heterogeneity. The fixed-effects model was applied for studies with no obvious heterogeneity $\left(\mathrm{Ph}>0.05, I^{2}<50 \%\right)$; otherwise, the random-effects model was adopted ( $\left.\mathrm{Ph} \leq 0.05, I^{2} \geq 50 \%\right)$. Potential publication bias was assessed with Begg's Test and Egger's test. Sensitivity analysis was also performed to assess the stability of the results. A $P$ value less than 0.05 was considered statistically significant.

\section{Results}

\section{Study characteristics}

The literature retrieval process is detailed in Fig. 1. A total of 24 eligible articles were ultimately identified [12-34] and 2, 706 cancer patients were included in the present metaanalysis; the mean patient sample size was 113 (range, 28-362). The 24 included studies were from the United States, Africa, Asia, and Europe. Eighteen different solid tumor types were evaluated in our study: 2 Hodgkin's lymphomas, 2 breast cancers, 2 cervical cancers, 2 endometrial carcinomas, 2 esophageal squamous cell carcinomas, 2 gastric cancers, and 1 each of colorectal cancer, glioma, hepatocarcinoma, lung cancer, laryngeal squamous cell carcinoma, non-Hodgkin's lymphoma, nasopharyngeal carcinoma, ovarian cancer, osteosarcoma, oral squamous cell carcinoma, RCC, and vulvar squamous cell carcinoma. All cancerous specimens were well preserved before experiments were performed. Diagnoses were all made based on pathology. The main characteristics are summarized in Table 1.

\section{Increased IDO1 expression and overall survival}

Among the 24 eligible articles, the overall survival (OS) according to ID01 expression was reported in 18 articles. The random-effects model was adopted to estimate the pooled HRs and corresponding 95\% CIs. The results showed a small heterogeneity across studies $\left(I^{2}=46.0 \%, \mathrm{Ph}=0.020\right)$. The HR for the high ID01 expression group versus the low ID01 expression group was 2.03 (95\% CI: 1.56-2.63) (Fig. 2A). After stratification by study type, the HRs for the high ID01 expression group versus the low ID01 expression group were 3.62 (95\% CI: 2.19-5.97) in prospective studies and 1.74 (95\% CI: 1.33-2.29) in retrospective studies (Fig. 2B). After

Fig. 1. Flowchart showing the literature search and selection process.

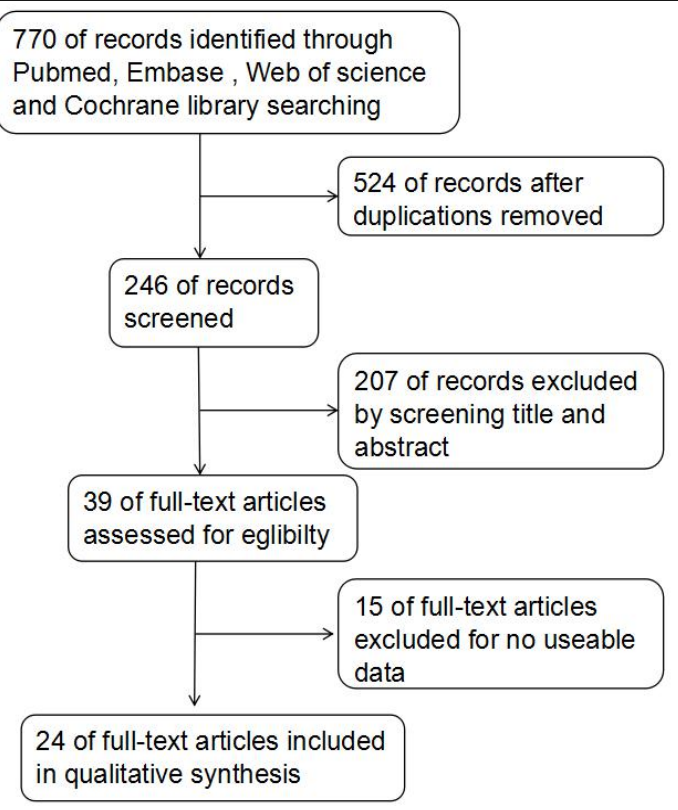


Table 1. Main characteristics of all included studies

\begin{tabular}{|c|c|c|c|c|c|c|c|c|c|c|}
\hline First author & $\begin{array}{l}\text { Publication } \\
\text { year }\end{array}$ & $\begin{array}{l}\text { Cancer } \\
\text { type }\end{array}$ & $\begin{array}{l}\text { Total } \\
\text { number }\end{array}$ & Tumor stage & $\begin{array}{l}\text { Follow- } \\
\text { up } \\
\text { (years) }\end{array}$ & $\begin{array}{l}\text { Detection } \\
\text { method }\end{array}$ & Outcome measure & Multivariate analysis & Treatment received & Study type \\
\hline Mitsuka & 2013 & GLI & 68 & $\begin{array}{l}15 / 60 \text { (I-II/III- } \\
\text { IV) }\end{array}$ & Over 13 & IHC & os & Yes & Surgical resection & Retrospective study \\
\hline Gao & 2009 & CRC & 71 & $\begin{array}{l}\text { 16/55 (I-II/III- } \\
\text { IV) }\end{array}$ & Over 6 & IHC & os & Yes & Radical resection & Retrospective study \\
\hline Inaba & 2010 & $\mathrm{CC}$ & 112 & $\begin{array}{l}\text { 67/45 (IB/IIA- } \\
\text { B) }\end{array}$ & 10 & $\mathrm{IHC}$ & $\begin{array}{l}\text { OS } \\
\text { DFS }\end{array}$ & Yes & Radical resection & Retrospective study \\
\hline Ino & 2006 & EC & 80 & $\begin{array}{l}\text { 64/16 (I-II/III- } \\
\text { IV) }\end{array}$ & Over 10 & $\mathrm{IHC}$ & $\begin{array}{l}\text { OS } \\
\text { PFS }\end{array}$ & Yes & Surgical treatment & Retrospective study \\
\hline Masaki & 2017 & $\mathrm{HL}$ & 52 & $\begin{array}{l}26 / 26 \text { (I-II/III- } \\
\text { IV) }\end{array}$ & 10 & $\mathrm{IHC}$ & $\begin{array}{l}\text { OS } \\
\text { PFS }\end{array}$ & Yes & Chemotherapy & $\begin{array}{l}\text { Prospective } \\
\text { study }\end{array}$ \\
\hline Pan & 2008 & $\mathrm{HCC}$ & 138 & $\mathrm{NR}$ & Over 6 & $\mathrm{IHC}$ & os & Yes & Surgical treatment & Retrospective study \\
\hline Soliman & 2013 & $\mathrm{BC}$ & 203 & $\begin{array}{l}\text { 92/92 (I-II/III- } \\
\text { IV) }\end{array}$ & Over 15 & IHC & os & Yes & Surgical treatment & Retrospective study \\
\hline Urakawa & 2009 & osc & 47 & 29/18 (IIA/IIB) & Over 15 & $\mathrm{IHC}$ & os & Yes & Chemotherapy & $\begin{array}{l}\text { Prospective } \\
\text { study }\end{array}$ \\
\hline Ye & 2013 & LSCC & 187 & $\begin{array}{l}\text { 78/109 (I-II/III- } \\
\text { IV) }\end{array}$ & Over 5 & IHC & $\begin{array}{l}\text { OS } \\
\text { DFS }\end{array}$ & Yes & Surgical treatment & $\begin{array}{l}\text { Prospective } \\
\text { study }\end{array}$ \\
\hline Ben-Haj-Ayed & 2016 & NPC & 71 & $\begin{array}{l}\text { 10/53 (I-II/III- } \\
\text { IV) }\end{array}$ & Over 6 & $\mathrm{IHC}$ & $\begin{array}{l}\text { OS } \\
\text { DFS }\end{array}$ & Yes & No report & $\begin{array}{l}\text { Prospective } \\
\text { study }\end{array}$ \\
\hline Brandacher & 2006 & $\mathrm{CC}$ & 143 & $\begin{array}{l}53 / 90 \text { (I-II/III- } \\
\text { IV) }\end{array}$ & Over 8 & $\mathrm{IHC}$ & os & Yes & Surgical resection & Retrospective study \\
\hline $\begin{array}{l}\text { Carvajal- } \\
\text { Hausdorf }\end{array}$ & 2017 & $\mathrm{BC}$ & 362 & $\begin{array}{l}278 / 63(\text { I-II } / \text { III- } \\
\text { IV) }\end{array}$ & Over 20 & IF & os & Yes & No report & Retrospective study \\
\hline Inaba & 2009 & oc & 60 & $\begin{array}{l}38 / 22(\mathrm{I}-\mathrm{II} / \mathrm{III}- \\
\text { IV) }\end{array}$ & 14 & $\mathrm{IHC}$ & $\begin{array}{l}\text { OS } \\
\text { PFS }\end{array}$ & No & Surgical treatment & Retrospective study \\
\hline Ino & 2008 & EC & 65 & $\begin{array}{l}\text { 50/15 (I-II/III- } \\
\text { IV) }\end{array}$ & Over 10 & IHC & PFS & Yes & Surgical treatment & Retrospective study \\
\hline Jia & 2015 & ESCC & 196 & $\begin{array}{l}113 / 83(\mathrm{I}-\mathrm{II} / \mathrm{III}- \\
\text { IV) }\end{array}$ & 5 & IHC & os & No & Surgical treatment & Retrospective study \\
\hline Karanikas & 2007 & $\mathrm{LC}$ & 28 & 19/9 (I-II/III-IV) & Over 10 & qPCR & NR & NR & Surgical treatment & Retrospective study \\
\hline Kim & 2016 & GC & 243 & $\begin{array}{l}\text { 161/82 (I-II/III- } \\
\text { IV) }\end{array}$ & Over 10 & $\mathrm{IHC}$ & $\begin{array}{l}\text { DFS } \\
\text { OS }\end{array}$ & NR & Surgical treatment & Retrospective study \\
\hline Lamier & 2011 & oscC & 88 & $\begin{array}{l}\text { 16/72 (I-II/III- } \\
\text { IV) }\end{array}$ & Over 10 & $\mathrm{IHC}$ & os & Yes & $\begin{array}{l}\text { Chemotherapy or } \\
\text { radiation therapy }\end{array}$ & Retrospective study \\
\hline Liu & 2017 & NHL & 57 & $\begin{array}{l}28 / 29 \text { (I-II/III- } \\
\text { IV) }\end{array}$ & Over 7 & IHC & os & Yes & Chemotherapy & $\begin{array}{l}\text { Prospective } \\
\text { study }\end{array}$ \\
\hline Ninomiya & 2011 & $\mathrm{HL}$ & 119 & $\begin{array}{l}42 / 77 \text { (I-II/III- } \\
\text { IV) }\end{array}$ & Over 5 & $\mathrm{IHC}$ & os & Yes & Chemotherapy & Retrospective study \\
\hline Riesenberg & 2007 & RCC & 55 & $\begin{array}{l}22 / 33(\mathrm{I}-\mathrm{II} / \mathrm{III}- \\
\text { IV) }\end{array}$ & Over 6 & $\mathrm{IHC}$ & os & Yes & Surgical treatment & Retrospective study \\
\hline Sznurkowski & 2011 & vSCC & 76 & NR & Over 10 & IHC & os & Yes & $\begin{array}{l}\text { Surgical treatment and } \\
\text { radiotherapy }\end{array}$ & Retrospective study \\
\hline Zhang & 2011 & ESCC & 135 & $\begin{array}{l}\text { 74/61 (I-II/III- } \\
\text { IV) }\end{array}$ & Over 6 & IHC & os & No & Surgical treatment & $\begin{array}{l}\text { Prospective } \\
\text { study }\end{array}$ \\
\hline Zhang & 2013 & GC & 50 & $16 / 34$ & NR & $\mathrm{IHC}$ & NR & NR & Surgical treatment & $\begin{array}{l}\text { Prospective } \\
\text { study }\end{array}$ \\
\hline
\end{tabular}

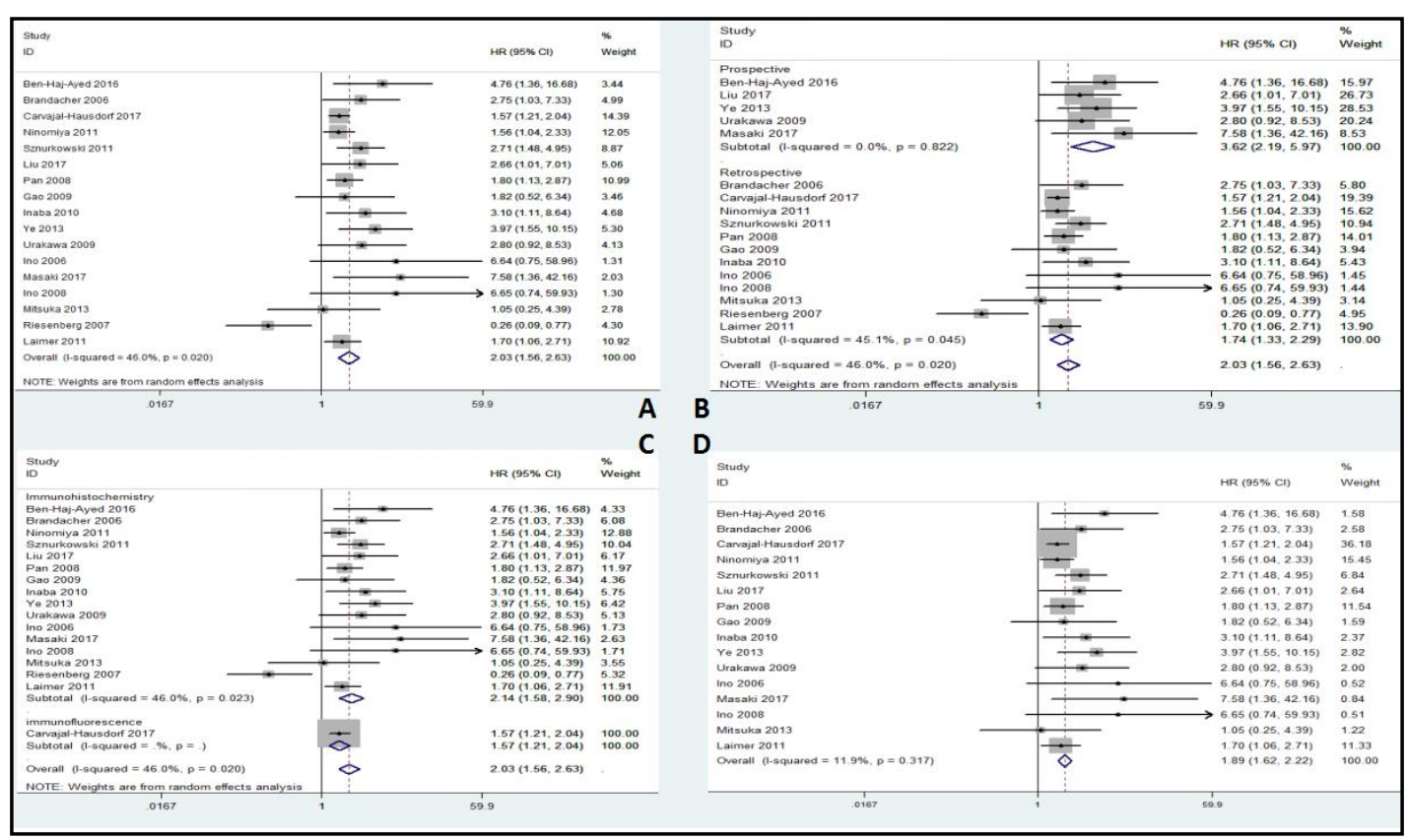

Fig. 2. Forest plot of the HR for the relationship between high ID01 expression and OS: (A) overall, (B) stratified by study type, (C) stratified by detection method, and (D) after exclusion of Riesenberg et al. 
stratification by detection method, the HR for the high ID01 expression group versus the low ID01 expression group was 2.14 (95\% CI: 1.58-2.90) in the immunohistochemistry subgroup (Fig. 2C). The results indicated that there was a significant difference in OS between the two groups. A significantly shorter OS was observed in patients with high ID01 expression versus those with low ID01 expression. Thus, we concluded that high expression of ID01 was associated with poor OS.

Increased ID01 expression and disease-free survival

Only 3 studies, comprising a total of 338 patients, provided appropriate data for analysis of disease-free survival (DFS). No severe statistical heterogeneity was observed across studies $\left(I^{2}=0 \% ; \mathrm{Ph}=0.784\right)$. The fixed-effects model was applied to analyze the pooled HRs with their corresponding 95\% CIs. The overall result indicated a significantly positive association between high expression of IDO1 and poor DFS (HR $=2.47,95 \%$ CI: 1.46-4.20) (Fig. 3).

\section{Associations between ID01 expression and clinicopathological parameters}

From the pooled results (Table 2), it was found that increased ID01 was significantly associated with tumor differentiation (OR $=1.81,95 \% \mathrm{CI}$ : 1.05-3.12) (Fig. 4), distant metastasis (OR $=1.45,95 \% \mathrm{CI}$ : 1.02-2.06) (Fig. 5), and poor clinical stage (OR $=1.89,95 \%$ CI: 1.13-3.17) (Fig. 6). However, no significant correlation was observed between increased ID01 expression and age, sex, lymph node metastasis, and tumor size (data not shown). Because of the insufficient data, we failed to detect a relationship between overexpression of ID01 and some other clinicopathological parameters.

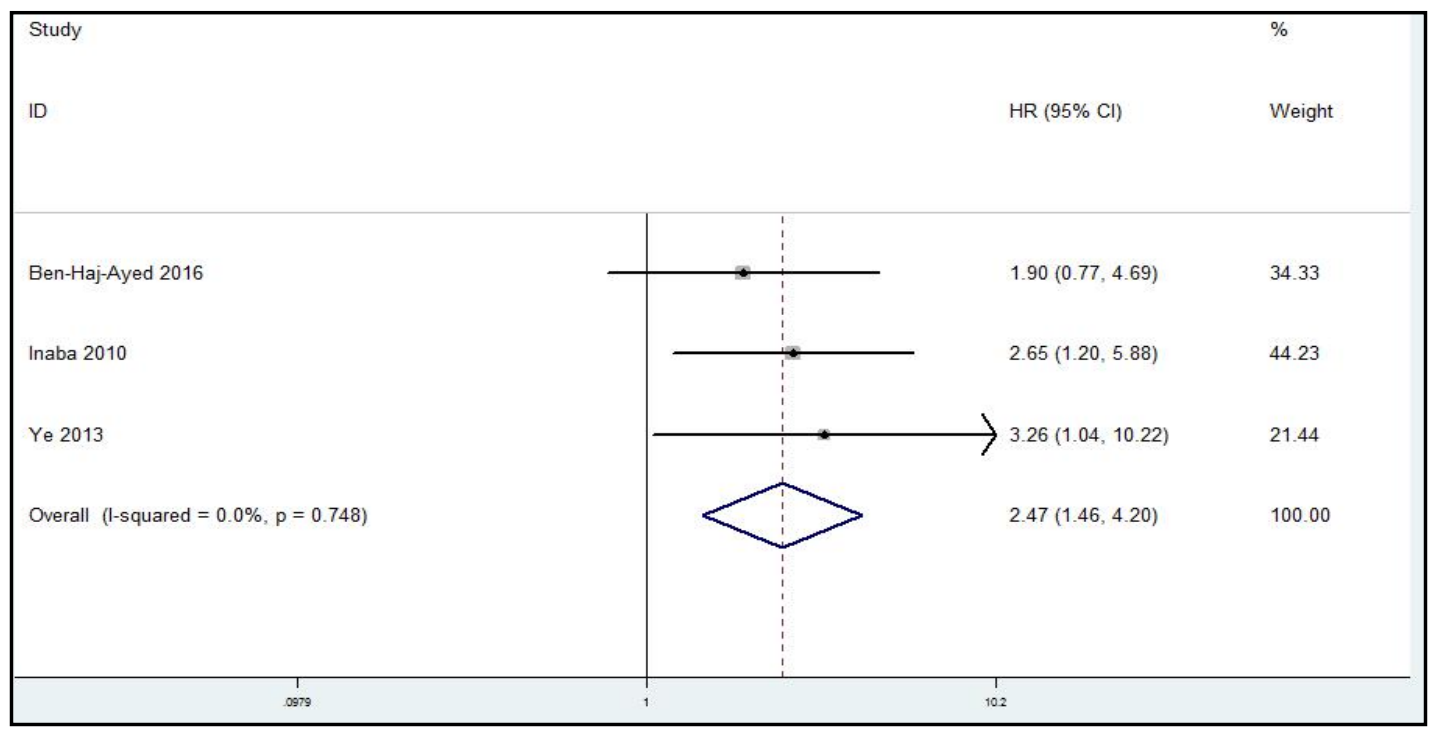

Fig. 3. Forest plot of HR for the relationship between high IDO1 expression and DFS.

Table 2. Meta-analysis results of the associations of increased ID01 expression with clinicopathological parameters

\begin{tabular}{|c|c|c|c|c|c|c|c|}
\hline Clinicopathological parameter & Studies (n) & Number of patients & OR $(95 \% \mathrm{CI})$ & $\mathrm{P}$ value $(95 \% \mathrm{CI})$ & $\mathrm{I}^{2}(\%)$ & $\mathrm{Ph}_{\mathrm{h}}$ & Model \\
\hline Age (<60 vs. $>60$ years) & 8 & 850 & $1.15(0.86-1.55)$ & 0.352 & 25.3 & 0.227 & Fixed-effects \\
\hline Sex (male vs. female) & 12 & 1191 & $1.27(0.98-1.64)$ & 0.071 & 26.5 & 0.184 & Fixed-effects \\
\hline TNM stage (III-IV vs. I-II) & 14 & 1629 & $1.89(1.13-3.17)$ & 0.015 & 76.5 & 0.000 & Random-effects \\
\hline Lymph node metastasis (yes vs. no) & 12 & 1475 & $1.56(0.84-2.89)$ & 0.157 & 78.9 & 0.000 & Random-effects \\
\hline Tumor differentiation (moderate/poor vs. well) & 9 & 1014 & $1.81(1.05-3.12)$ & 0.033 & 66.6 & 0.002 & Random-effects \\
\hline Tumor size ( $>5$ vs. $<5 \mathrm{~cm})$ & 4 & 376 & $1.43(0.57-3.57)$ & 0.446 & 74.6 & 0.008 & Random-effects \\
\hline Distant metastasis (yes vs. no) & 7 & 738 & $1.45(1.02-2.06)$ & 0.039 & 14.6 & 0.318 & Fixed-effects \\
\hline
\end{tabular}




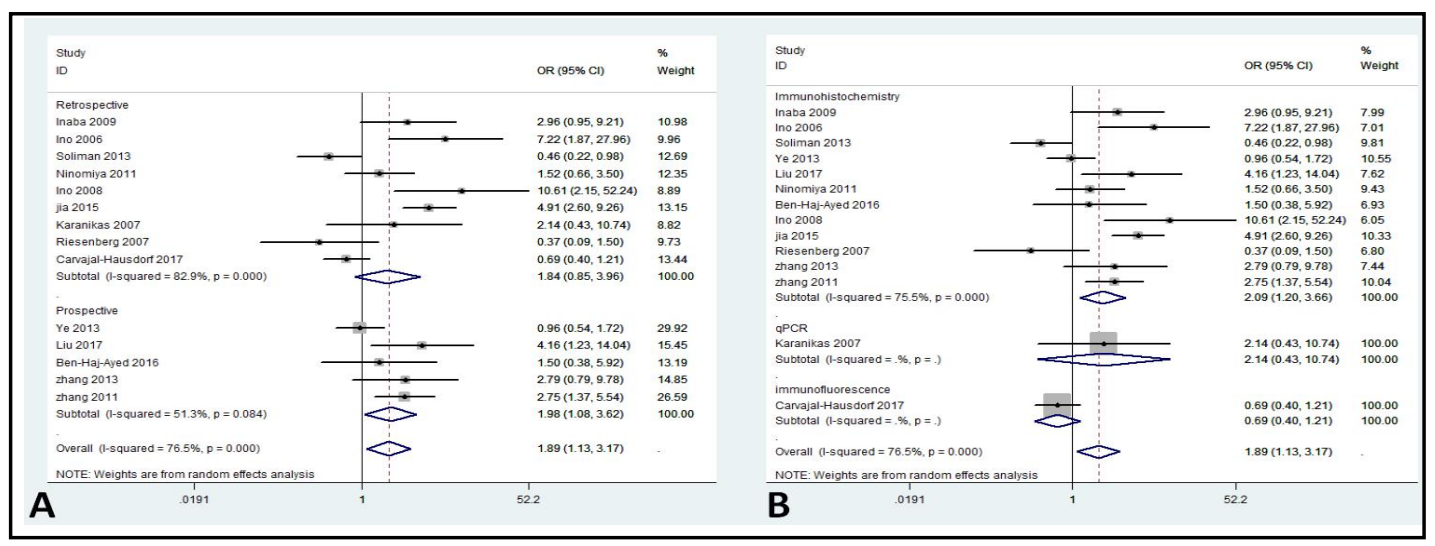

Fig. 4. Forest plot of OR for the relationship between high ID01 expression and TNM: (A) stratified by study type, and (B) stratified by detection method.

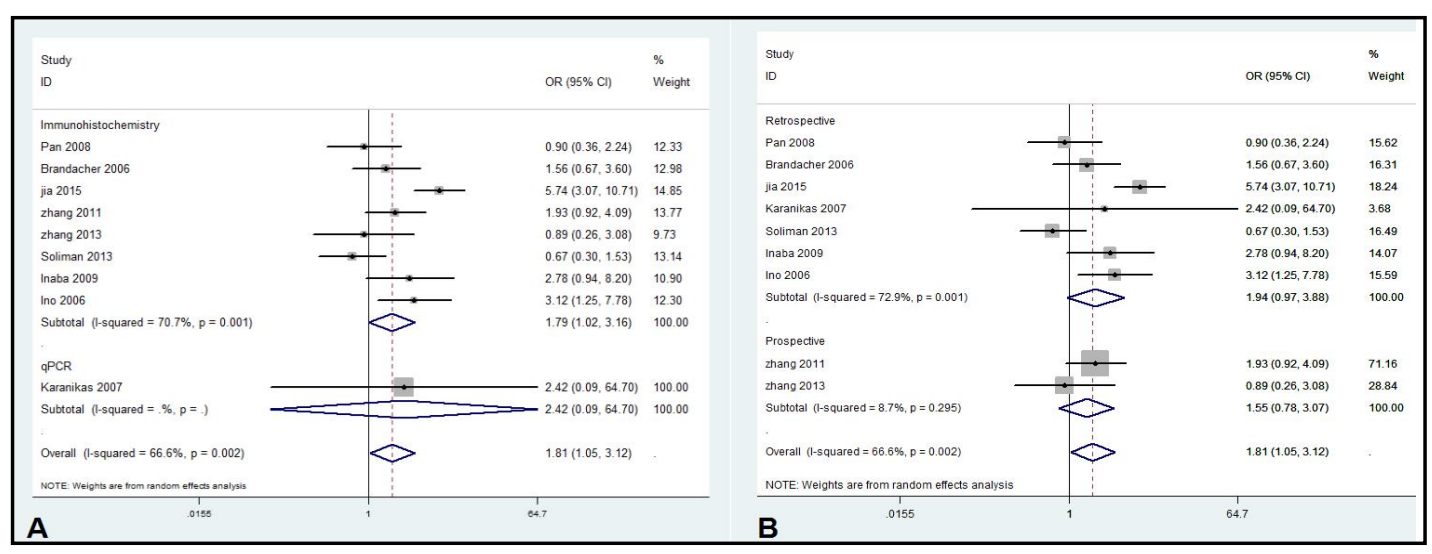

Fig. 5. Forest plot of OR for the relationship between high ID01 expression and tumor differentiation: (A) stratified by study type, and (B) stratified by detection method.

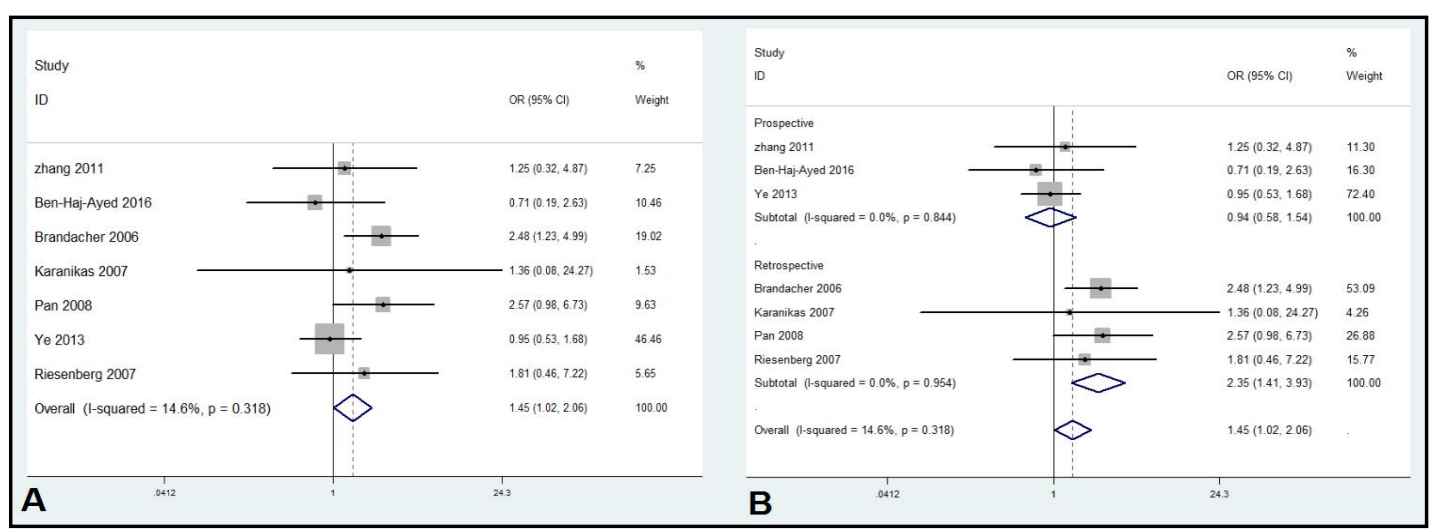

Fig. 6. Forest plot of OR for the relationship between high IDO1 expression and distant metastasis: (A) overall, and (B) stratified by study type.

\section{Sensitivity analysis}

For meta-analysis of the association between the ID01 expression level and OS, sensitivity analysis was performed by removing each study in turn from the pooled analysis. This process aimed to assess the influence of the removed data set on the overall HRs. The result was not significantly influenced by the exclusion of any study, indicating the robustness of the results. 


\section{Cellular Physiology Cell Physiol Biochem 2018;49:134-143 \begin{tabular}{ll|l} 
DOI: 10.1159/000492849 & (0 2018 The Author(s). Published by S. Karger AG, Basel \\
www.karger.com/cpb
\end{tabular}

\section{Publication bias}

For meta-analysis of the association between ID01 expression levels and OS, Begg's Test and Egger's test were adopted to test for publication bias. The results showed no publication bias among the included studies (Fig. 7).

\section{Discussion}

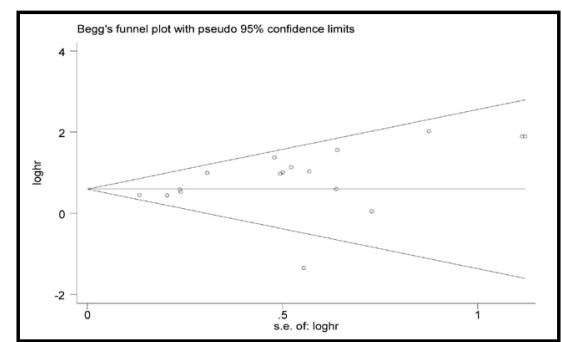

Fig. 7. Publication bias results for OS.

Tumor immune escape plays an important role in the development and metastasis of tumors [35]. Multiple immunosuppressive mechanisms in the tumor microenvironment can impair the functions of tumor-infiltrating lymphocytes. One of these immunosuppressive mechanisms is mediated by the IDO enzyme [27]. In 1998, Munn et al. found that ID01 could prevent fetus rejection by allowing maternal-fetal immune tolerance in the mouse placenta [36]. Subsequent studies showed that a local depletion of tryptophan and the accumulation of toxic downstream products mediated by ID01 could affect T-cell proliferation, metabolism, and functions [6,37]. Moreover, ID01 was also expressed in tumor cells as well as in various non-tumor cells in the tumor microenvironment, such as fibroblasts, endothelial cells, eosinophils, dendritic cells, and macrophages [2, 38, 39]. In addition, the expression of IDO by tumor cells can result in a decrease in the number of tumor-infiltrating lymphocytes in various tumors [40]. Many studies subsequently demonstrated that the expression of ID01 in tumors was associated with patients' clinical outcome [12-34]. However, the results were inconsistent. The expression of ID01 predicted a poor clinical outcome in many tumors, such as ovarian adenocarcinomas, colorectal adenocarcinomas, and endometrial and esophageal cancer [12-16]. In contrast, patients with high ID01 expression in some tumors, such as RCC and hepatocellular carcinoma, have a longer survival [37]. The results of this meta-analysis showed a shorter OS in patients with high expression of ID01 (HR $=2.03,95 \%$ CI: 1.562.63). Furthermore, poorer DFS was observed in patients with high expression of IDO1 (HR $=2.47,95 \%$ CI: $1.46-4.20$ ), implying that the expression of IDO was a hazardous factor for the clinical outcome of cancer patients. Moreover, increased ID01 was significantly associated with tumor differentiation (OR $=1.81,95 \% \mathrm{CI}$ : 1.05-3.12), distant metastasis (OR $=1.45$, $95 \% \mathrm{CI}: 1.02-2.06)$, and poor clinical stage (OR $=1.89,95 \% \mathrm{CI}: 1.13-3.17)$. This showed that more malignant tumor cells could express more ID01, which promotes tumor development and metastasis.

However, there are some limitations to our meta-analysis. First, the total sample size was relatively small and we failed to detect a relationship between overexpression of ID01 and some clinicopathological parameters. Second, there was some minor heterogeneity in our meta-analysis result. Subsequent regression analysis found that publication year and publication country were not associated with the heterogeneity (data not shown). Although the sensitivity analysis showing that the result was not significantly influenced by the exclusion of any study, we excluded a study by Riesenberg et al. [12] and found that the $I^{2}$ value fell from $46 \%$ to $11.9 \%$ (Fig. 2D), demonstrating that the heterogeneity is mainly due to this single study. This study was the only one of the included studies to show that the expression of IDO1 was associated with better OS in RCC patients, which may be why this study caused the heterogeneity. In Riesenberg et al. [12], the explanation for the association between ID01 expression and improved survival in RCC is that IDO is nearly exclusively expressed in the endothelial cells of predominantly newly formed blood vessels, which limit the influx of tryptophan from the blood to the tumor or generate tumor-toxic metabolites, thus restricting tumor growth and contributing to survival. Thus, the location of ID01 expression in different solid tumors may also result in the observed effects on patient survival. Third, many studies did not meet the inclusion criterion and were thus excluded, including some contradictory results, which may have caused a deviation of the result of this 


\section{Cellular Physiology Cell Physiol Biochem 2018;49:134-143 \begin{tabular}{ll|l} 
DOI: 10.1159/000492849 & $\begin{array}{l}\text { O 2018 The Author(s). Published by S. Karger AG, Basel } \\
\text { www.karger.com/cpb }\end{array}$ \\
\hline and Biochemistry
\end{tabular} \\ Yu et al.: The Expression of IDO1 in Human Tumors}

meta-analysis. Fourth, the consistency of antibody staining and the cutoffs used to assign patients to high or low ID01 expressions differed among studies, which may also influence the results of the meta-analysis. Fifth, prospective and retrospective studies are included together in this meta-analysis. A subgroup analysis of study types found that there was a slight difference between the results of the subgroup analysis and overall results, which may also cause a deviation of the result of this meta-analysis. Therefore, larger, multicenter, and higher-quality studies with a unified criterion for determining ID01 expression are necessary to validate the results of this study.

\section{Abbreviations}

BC (breast cancer); CC (cervical cancer); CRC (colorectal cancer); EC (endometrial carcinoma); ESCC (esophageal squamous cell carcinoma); GC (gastric cancer); GLI (glioma); HCC (hepatocarcinoma); HL (Hodgkin's lymphoma); LC (lung cancer); LSCC (laryngeal squamous cell carcinoma); NLH (non-Hodgkin's lymphoma); OSC (osteosarcoma); NPC (nasopharyngeal carcinoma); OC (ovarian cancer); OSCC (oral squamous cell carcinoma); RCC (renal cell carcinoma); vSCC (vulvar squamous cell carcinoma); DFS (disease-free survival); PFS (progression-free survival); OS (overall survival); NR (not reported); IHC (immunohistochemistry); IF (immunofluorescence); qPCR (quantitative real-time polymerase chain reaction).

\section{Acknowledgements}

This work was supported by grants from National Natural Science Foundation of China (Grant No. 81560389 to ZMZ). In addition, the first author herein thanks Wen-Cong He for his company and valuable support.

\section{Disclosure Statement}

No conflicts of interest exist.

\section{References}

1 Fallarino F, Grohmann U, Vacca C, Orabona C, Spreca A, Fioretti MC, Puccetti P: T cell apoptosis by kynurenines. Adv Exp Med Biol 2003;527:183-190.

-2 Uyttenhove C, Pilotte L, Theate I, Stroobant V, Colau D, Parmentier N, Boon T, Van den Eynde BJ: Evidence for a tumoral immune resistance mechanism based on tryptophan degradation by indoleamine 2, 3-dioxygenase. Nat Med 2003;9:1269-1274.

-3 Thackray SJ, Mowat CG, Chapman SK: Exploring the mechanism of tryptophan 2, 3-dioxygenase. Biochem Soc Trans 2008;36:1120-1123.

-4 Wang D, Saga Y, Mizukami H, Sato N, Nonaka H, Fujiwara H, Takei Y, Machida S, Takikawa O, Ozawa K, Suzuki M: Indoleamine-2, 3-dioxygenase, an immunosuppressive enzyme that inhibits natural killer cell function, as a useful target for ovarian cancer therapy. Int J Oncol 2012;40:929-934.

5 Molano A, Illarionov PA, Besra GS, Putterman C, Porcelli SA: Modulation of invariant natural killer T cell cytokine responses by indoleamine 2, 3-dioxygenase. Immunol Lett 2008;117:81-90.

-6 Frumento G, Rotondo R, Tonetti M, Damonte G, Benatti U, Ferrara GB: Tryptophan-derived catabolites are responsible for inhibition of $\mathrm{T}$ and natural killer cell proliferation induced by indoleamine 2 , 3-dioxygenase. J Exp Med 2002;196:459-468. 


\section{Cellular Physiology Cell Physiol Biochem 2018;49:134-143 \begin{tabular}{ll|l} 
and Biochemistry Published online: 22 August, 2018 & $\begin{array}{l}\text { (c) } 2018 \text { The Author(s). Published by S. Karger AG, Basel } \\
\text { www.karger.com/cpb }\end{array}$ \\
\hline
\end{tabular} \\ Yu et al.: The Expression of IDO1 in Human Tumors}

7 Gandhi R, Kumar D, Burns EJ, Nadeau M, Dake B, Laroni A, Kozoriz D, Weiner HL, Quintana FJ: Activation of the aryl hydrocarbon receptor induces human type 1 regulatory T cell-like and Foxp3(+) regulatory T cells. Nat Immunol 2010;11:846-853.

-8 Jenabian MA, Patel M, Kema I, Kanagaratham C, Radzioch D, Thebault P, Lapointe R, Tremblay C, Gilmore N, Ancuta P, Routy JP: Distinct tryptophan catabolism and Th17/Treg balance in HIV progressors and elite controllers. PLoS One 2013;8:e78146.

-9 Favre D, Mold J, Hunt PW, Kanwar B, Loke P, Seu L, Barbour JD, Lowe MM, Jayawardene A, Aweeka F, Huang Y, Douek DC, Brenchley JM, Martin JN, Hecht FM, Deeks SG, McCune JM: Tryptophan catabolism by indoleamine 2, 3-dioxygenase 1 alters the balance of TH17 to regulatory T cells in HIV disease. Sci Transl Med 2010;2:32ra36.

10 Mezrich JD, Fechner JH, Zhang X, Johnson BP, Burlingham WJ, Bradfield CA: An interaction between kynurenine and the aryl hydrocarbon receptor can generate regulatory T cells. J Immunol 2010;185:31903198.

-11 Munn DH, Sharma MD, Hou D, Baban B, Lee JR, Antonia SJ, Messina JL, Chandler P, Koni PA, Mellor AL: Expression of indoleamine 2, 3-dioxygenase by plasmacytoid dendritic cells in tumor-draining lymph nodes. J Clin Invest 2004;114:280-290.

12 Riesenberg R, Weiler C, Spring O, Eder M, Buchner A, Popp T, Castro M, Kammerer R, Takikawa O, Hatz RA, Stief CG, Hofstetter A, Zimmermann W: Expression of indoleamine 2, 3-dioxygenase in tumor endothelial cells correlates with long-term survival of patients with renal cell carcinoma. Clin Cancer Res 2007;13:6993-7002.

13 Ino K, Yoshida N, Kajiyama H, Shibata K, Yamamoto E, Kidokoro K, Takahashi N, Terauchi M, Nawa A, Nomura S, Nagasaka T, Takikawa O, Kikkawa F: Indoleamine 2, 3-dioxygenase is a novel prognostic indicator for endometrial cancer. Br J Cancer 2006;95:1555-1561.

14 Gao YF, Peng RQ Li J, Ding Y, Zhang X, Wu XJ, Pan ZZ, Wan DS, Zeng YX, Zhang XS: The paradoxical patterns of expression of indoleamine 2, 3-dioxygenase in colon cancer. J Transl Med 2009;7:71.

15 Inaba T, Ino K, Kajiyama H, Shibata K, Yamamoto E, Kondo S, Umezu T, Nawa A, Takikawa O, Kikkawa F: Indoleamine 2, 3-dioxygenase expression predicts impaired survival of invasive cervical cancer patients treated with radical hysterectomy. Gynecol Oncol 2010;117:423-428.

16 Soliman H, Rawal B, Fulp J, Lee JH, Lopez A, Bui MM, Khalil F, Antonia S, Yfantis HG, Lee DH, Dorsey TH, Ambs S: Analysis of indoleamine 2-3 dioxygenase (ID01) expression in breast cancer tissue by immunohistochemistry. Cancer Immunol Immunother 2013;62:829-837.

17 Zhang G, Liu WL, Zhang L, Wang JY, Kuang MH, Liu P, Lin YH, Dai SQ, Du J: Involvement of indoleamine 2, 3-dioxygenase in impairing tumor-infiltrating CD8 T-cell functions in esophageal squamous cell carcinoma. Clin Dev Immunol 2011;2011:384726.

18 Ye J, Liu H, Hu Y, Li P, Zhang G, Li Y: Tumoral indoleamine 2, 3-dioxygenase expression predicts poor outcome in laryngeal squamous cell carcinoma. Virchows Arch 2013;462:73-81.

19 Ninomiya S, Hara T, Tsurumi H, Hoshi M, Kanemura N, Goto N, Kasahara S, Shimizu M, Ito H, Saito K, Hirose Y, Yamada T, Takahashi T, Seishima M, Takami T, Moriwaki H: Indoleamine 2, 3-dioxygenase in tumor tissue indicates prognosis in patients with diffuse large B-cell lymphoma treated with R-CHOP. Ann Hematol 2011;90:409-416.

20 Liu XQ, Lu K, Feng LL, Ding M, Gao JM, Ge XL, Wang X: Up-regulated expression of indoleamine 2, 3-dioxygenase 1 in non-Hodgkin lymphoma correlates with increased regulatory T-cell infiltration. Leuk Lymphoma 2014;55:405-414.

21 Zhang R, Liu H, Li F, Li H, Yu J, Ren X: The correlation between the subsets of tumor infiltrating memory T cells and the expression of indoleamine 2, 3-dioxygenase in gastric cancer. Dig Dis Sci 2013;58:3494-3502.

22 Urakawa H, Nishida Y, Nakashima H, Shimoyama Y, Nakamura S, Ishiguro N: Prognostic value of indoleamine 2, 3-dioxygenase expression in high grade osteosarcoma. Clin Exp Metastasis 2009;26:10051012.

23 Sznurkowski JJ, Zawrocki A, Emerich J, Sznurkowska K, Biernat W: Expression of indoleamine 2, 3-dioxygenase predicts shorter survival in patients with vulvar squamous cell carcinoma (vSCC) not influencing on the recruitment of FOXP3-expressing regulatory T cells in cancer nests. Gynecol Oncol 2011;122:307-312. 


\section{Cellular Physiology Cell Physiol Biochem 2018;49:134-143 \begin{tabular}{l|l|l} 
DOI: 10.1159/000492849 & $\begin{array}{l}\text { O 2018 The Author(s). Published by S. Karger AG, Basel } \\
\text { www.karger.com/cpb }\end{array}$
\end{tabular}}

Yu et al.: The Expression of IDO1 in Human Tumors

-24 Pan K, Wang H, Chen MS, Zhang HK, Weng DS, Zhou J, Huang W, Li JJ, Song HF, Xia JC: Expression and prognosis role of indoleamine 2, 3-dioxygenase in hepatocellular carcinoma. J Cancer Res Clin Oncol 2008;134:1247-1253.

25 Masaki A, Ishida T, Maeda Y, Ito A, Suzuki S, Narita T, Kinoshita S, Takino H, Yoshida T, Ri M, Kusumoto S, Komatsu H, Inagaki H, Ueda R, Choi I, Suehiro Y, Iida S: Clinical significance of tryptophan catabolism in Hodgkin lymphoma. Cancer Sci 2018;109:74-83.

-26 Laimer K, Troester B, Kloss F, Schafer G, Obrist P, Perathoner A, Laimer J, Brandacher G, Rasse M, Margreiter $\mathrm{R}$, Amberger A: Expression and prognostic impact of indoleamine 2, 3-dioxygenase in oral squamous cell carcinomas. Oral Oncol 2011;47:352-357.

-27 Ben-Haj-Ayed A, Moussa A, Ghedira R, Gabbouj S, Miled S, Bouzid N, Tebra-Mrad S, Bouaouina N, Chouchane L, Zakhama A, Hassen E: Prognostic value of indoleamine 2, 3-dioxygenase activity and expression in nasopharyngeal carcinoma. Immunol Lett 2016;169:23-32.

28 Brandacher G, Perathoner A, Ladurner R, Schneeberger S, Obrist P, Winkler C, Werner ER, Werner-Felmayer G, Weiss HG, Gobel G, Margreiter R, Konigsrainer A, Fuchs D, Amberger A: Prognostic value of indoleamine 2, 3-dioxygenase expression in colorectal cancer: effect on tumor-infiltrating T cells. Clin Cancer Res 2006;12:1144-1151.

29 Carvajal-Hausdorf DE, Mani N, Velcheti V, Schalper KA, Rimm DL: Objective measurement and clinical significance of ID01 protein in hormone receptor-positive breast cancer. J Immunother Cancer 2017;5:81.

- 30 Inaba T, Ino K, Kajiyama H, Yamamoto E, Shibata K, Nawa A, Nagasaka T, Akimoto H, Takikawa O, Kikkawa F: Role of the immunosuppressive enzyme indoleamine 2, 3-dioxygenase in the progression of ovarian carcinoma. Gynecol Oncol 2009;115:185-192.

-31 Ino K, Yamamoto E, Shibata K, Kajiyama H, Yoshida N, Terauchi M, Nawa A, Nagasaka T, Takikawa O, Kikkawa F: Inverse correlation between tumoral indoleamine 2, 3-dioxygenase expression and tumorinfiltrating lymphocytes in endometrial cancer: its association with disease progression and survival. Clin Cancer Res 2008;14:2310-2317.

32 Jia Y, Wang H, Wang Y, Wang T, Wang M, Ma M, Duan Y, Meng X, Liu L: Low expression of Bin1, along with high expression of IDO in tumor tissue and draining lymph nodes, are predictors of poor prognosis for esophageal squamous cell cancer patients. Int J Cancer 2015;137:1095-1106.

-33 Karanikas V, Zamanakou M, Kerenidi T, Dahabreh J, Hevas A, Nakou M, Gourgoulianis KI, Germenis AE: Indoleamine 2, 3-dioxygenase (IDO) expression in lung cancer. Cancer Biol Ther 2007;6:1258-1262.

34 Kim JW, Nam KH, Ahn SH, Park DJ, Kim HH, Kim SH, Chang H, Lee JO, Kim YJ, Lee HS, Kim JH, Bang SM, Lee JS, Lee KW: Prognostic implications of immunosuppressive protein expression in tumors as well as immune cell infiltration within the tumor microenvironment in gastric cancer. Gastric Cancer 2016;19:4252.

-35 Villalba M, Rathore MG, Lopez-Royuela N, Krzywinska E, Garaude J, Allende-Vega N: From tumor cell metabolism to tumor immune escape. Int J Biochem Cell Biol 2013;45:106-113.

-36 Munn DH, Zhou M, Attwood JT, Bondarev I, Conway SJ, Marshall B, Brown C, Mellor AL: Prevention of allogeneic fetal rejection by tryptophan catabolism. Science 1998;281:1191-1193.

-37 Brochez L, Chevolet I, Kruse V: The rationale of indoleamine 2, 3-dioxygenase inhibition for cancer therapy. Eur J Cancer 2017;76:167-182.

38 Astigiano S, Morandi B, Costa R, Mastracci L, D’Agostino A, Ratto GB, Melioli G, Frumento G: Eosinophil granulocytes account for indoleamine 2, 3-dioxygenase-mediated immune escape in human non-small cell lung cancer. Neoplasia 2005;7:390-396.

-39 Choe JY, Yun JY, Jeon YK, Kim SH, Park G, Huh JR, Oh S, Kim JE: Indoleamine 2, 3-dioxygenase (IDO) is frequently expressed in stromal cells of Hodgkin lymphoma and is associated with adverse clinical features: a retrospective cohort study. BMC Cancer 2014;14:335.

40 Cesario A, Rocca B, Rutella S: The interplay between indoleamine 2, 3-dioxygenase 1 (IDO1) and cyclooxygenase (COX)-2 in chronic inflammation and cancer. Curr Med Chem 2011;18:2263-2271. 